INTIQAD: JURNAL AGAMA DAN PENDIDIKAN ISLAM

ISSN 1979-9950 (print) || ISSN 2598-0033 (online), http://jurnal.umsu.ac.id/index.php/intiqad DOI: https://doi.org/10.30596/intiqad.v11i1.2019

Vol. 11, No. 1 (Juni 2019)

\title{
Perbedaan Hasil Belajar Pada Mata Pelajaran Pendidikan Agama Islam (PAI) Berdasarkan Keaktifan belajar Siswa Kelas X SMA Swasta Al-Hidayah Medan
}

\author{
Mavianti \\ Universitas Muhammadiyah Sumatera Utara \\ email:mavianti@umsu.ac.id
}

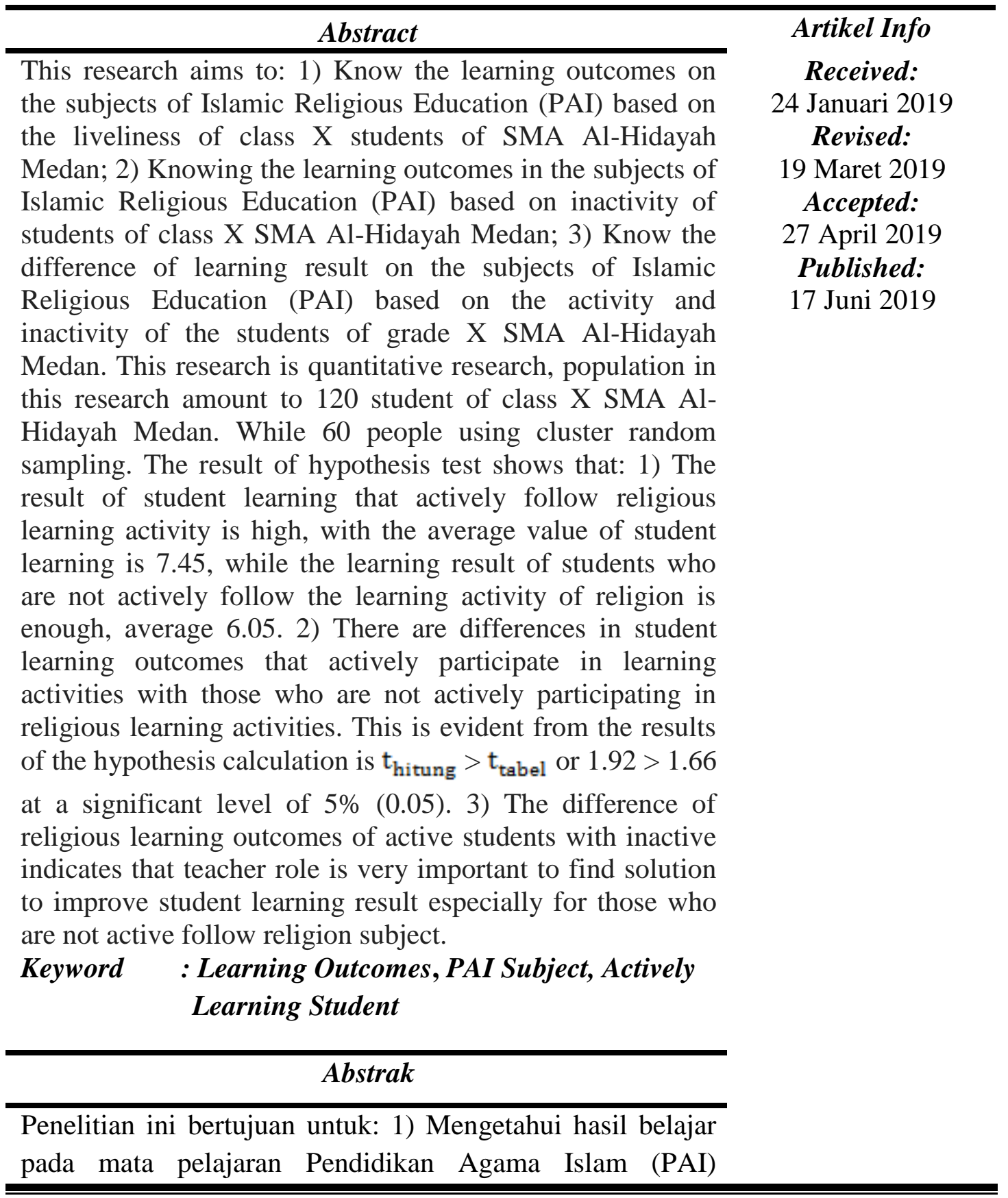


berdasarkan keaktifan belajar siswa kelas X SMA AlHidayah Medan; 2) Mengetahui hasil belajar pada mata pelajaran Pendidikan Agama Islam (PAI) berdasarkan ketidakaktifan belajar siswa kelas X SMA Al-Hidayah Medan; 3) Mengetahui perbedaan hasil belajar pada mata pelajaran Pendidikan Agama Islam (PAI) berdasarkan keaktifan dan ketidakaktifan belajar siswa kelas X SMA AlHidayah Medan.Penelitian ini merupakan penelitian kuantitatif, populasi dalam penelitian ini berjumlah 120 orang siswa kelas X SMA Al-Hidayah Medan. Sedangkan sample berjumlah 60 orang dengan menggunakan claster random sampling. Hasil pengujian hipotesis menunjukkan bahwa: 1) Hasil belajar siswa yang aktif mengikuti kegiatan belajar agama tergolong tinggi, dengan nilai rata-rata belajar siswa yaitu 7,45, sedang hasil belajar siswa yang tidak aktif mengikuti kegiatan belajar agama tergolong cukup, dengan nilai rata-rata 6,$05 ; 2$ ) Ada perbedaan hasil belajar siswa yang aktif mengikuti kegiatan belajar dengan yang tidak aktif mengikuti kegiatan belajar agama. Hal ini terbukti dari hasil perhitungan hipotesis yaitu $t_{\text {hitung }}>t_{\text {tabel }}$ atau 1,92> 1,66 pada taraf signifikan 5\% $(0,05) ; 3)$ Adanya perbedaan hasil belajar agama siswa yang aktif dengan yang tidak aktif menunjukkan bahwa peranan guru sangat penting untuk mencari solusi terhadap peningkatan hasil belajar siswa khususnya bagi mereka yang tidak aktif mengikuti pelajaran agama.

\section{Kata Kunci :Hasil Belajar, Mata Pelajaran PAI, Keaktifan Belajar Siswa}

\section{A. Pendahuluan}

Pendidikan di sekolah sebagai proses bimbingan yang terencana, terarah dan terpadu dalam membina potensi anak untuk menguasai nilai-nilai dan keterampilan sangat menetukan corak masa depan suatu bangsa. Untuk itu penunukan kualitas pendidikan merupakan suatu masalah yang tidak boleh diabaikan. Peningkatan kualitas pendidikan tersebut diantaranya dimulai dari peningkatan kualitas pembelajaran, hal ini yang merupakan hal yang berhubungan langsung dengan seorang guru. 
Vol. 11, No. 1 (Juni 2019)

Pembelajaran yang efektif adalah proses pembelajaran yang berhasil atau yang mencapai tujuan sebagaimana ditetapkan dengan mendayagunakan sumber daya belajar yang ada. Guru menggunakan kemampuan profesionalnya untuk mengerahkan sumber daya yang ada sehingga tercapai tujuan pengajaran yang ditetapkan. ${ }^{1}$

Sebagaimana yang dikatakan oleh Abdul Aziz Rambe yaitu: "Pendidikan dapat menciptakan siswa yang berkualitas, mandiri, kreativitas yang berilmu pengetahuan dan mampu menguasai teknologi sesuai dengan perkembangan zaman."

Dalam meningkatkan keaktifan siswa ini dapat dilancarkan dengan menciptakan situasi pembelajaran yang melibatkan siswa. Guru sebagai fasilitator dalam pembelajaran hendaknya menggunakan berbagai metode/cara yang sesuai yang melibatkan siswanya. Penggunaaan metode yang tepat dengan

${ }^{1}$ Syafaruddin dan Irwan Nst.Manajemen Pembelajaran, (Jakarta: Quantum Teaching Press, 2005), h.212

${ }^{2}$ AR. Tilaar. Pendidikan Non Formal Sebagai Ide Eksplosif dalam Pendidikan, (Jakarta: Konvensi Nasional,1996), h. 1 menyesuaikannya terhadap materi yang diajarkan akan memudahkan siswa memahami pelajaran yang diajarkan oleh guru sekaligus dapat meningkatkan motivasi dan minat belajar siswa itu sendiri. Bidang studi agama Islam diarahkan untuk mendorong, membimbing, mengembangkan dan membina siswa untuk mengetahui, memahami dan menghayati syariat Islam untuk dapat diamalkan dan dijadikan pedoman dalam kehidupan sehari-hari. ${ }^{3}$

Meskipun demikian setiap siswa memperoleh hasil belajar khususnya bidang studi agama Islam yang berbeda, hal ini sesuai dengan keaktifan belajar siswa. Karena keaktifan belajar siswa dapat mempengaruhi terhadaap kemampuan mempelajari, memahami dan hasil yang diperoleh dalam belajar. Hasil belajar yang dimaksudkan adalah hasil belajar ditinjau dari sisi kualitas dan kuantitas belajar siswa melalui tes atau ujian yang dilakukan sesuai dengan ketentuan yang ditetapkan.

Berdasarkan latar belakang tersebut di atas menjadi dasar pemikiran bagi penulis sehingga menetapkan judul:

${ }^{3}$ Hafsah.Ilmu Fiqh, (Medan: PT. Madju. Medan, 2006), h. 23 
Perbedaan Hasil Belajar Pada Mata Pelajaran Pendidikan Agama Islam (PAI) Berdasarkan Keaktifan Belajar Siswa Di Kelas X SMA Swasta AlHidayah Medan.

\section{B. Pengertian Hasil Belajar \\ 1. Pengertian Belajar}

Secara terminologi pengertian belajar dapat diketahui berdasarkan pendapat beberapa ahli. Abu Ahmadi berpendapat bahwa: "Belajar adalah proses dimana tingkah laku ditimbulkan atau diubah melalui praktek atau latihan."

Berdasarkan pengertian diatas dapat ditegaskan bahwa kegiatan belajar merupakan suatu tindakan atau usaha untuk dapat melakukan perubahan pada diri pribadi anak didik sehingga ia dapat mengembangkan potensi dirinya, karena kegiatan belajar merupakan suatu langkah untuk mengembangkan kecerdasan yang dimiliki anak didik sehingga perkembangan yang terjadi dewasa ini dapat diikiuti. Dengan kata lain belajar adalah suatu rangkaian proses kegiatan respon yang terjadi dalam suatu rangkaian belajar mengajar yang berakhir pada terjadinya perubahan

\footnotetext{
${ }^{4}$ Abu Ahmadi. Psikologi Belajar, (Jakarta: Rineka Cipta,1997), h. 56
}

tingkah laku baik jasmaniyah maupun rohaniyah akibat pengalaman atau pengetahuan yang diperoleh.

Dengan demikian dalam kegiatan belajar senantiasa diusahakan untuk mengembangkan ilmu pengetahuan dan melakukan perubahan terhadap tingkah laku.Upaya pengembangan ilmu pengetahuan dapat dilakukan dengan terus belajar dan mengkaji berbagai disiplin ilmu sampai batas kemampuan ilmu yang dimiliki dengan belajar diharapkan terjadi peningkatan pengetahuan, keterampilan berpikir, kreativitas dan sebagainya.

Asumsi yang mendasari pembelajaran berfikir adalah bahwa pengethuan itu tidak datang dari luar, akan tetapi dibentuk oleh individu itu sendiri dalam struktur kognitif yang dimilikinya. Atas dasar asumsi itulah kalau pembelajaran berfikir bukanlah memindahkan pengetahuan dari guru ke siswa, melainkan suatu aktivitas yang memungkinkan siswa dapat membangun sendiri pengetahuannya.

Mulyasa mengatakan dalam bukunya bahwa: "Dalam proses pembelajaran adalah untuk mengembangkan aktivitas dan 
Vol. 11, No. 1 (Juni 2019)

kreativitas peserta didik melalui berbagai interaksi dan pengalaman belajar." 5

Dengan adanya interaksi maka aktivitas dan kreativitas peserta didik dapat terbentuk. Namun dalam pelaksanannya sering kita tidak menyadari bahwa banyak kegiatan pembelajaran yang dilaksanakan justru menghambat aktivitas dan kreativitas peserta didik.

Menurut Sumardi Suryabrata yang memberikan defenisi belajar adalah:

1) Bahwa belajar itu membawa perubahan.

2) Bahwa perubahan itu pada pokoknya adalahdidapatkan kecakapan baru.

3) Bahwa perubahan itu terjadi karena usaha (dengan sengaja). ${ }^{6}$

Selanjutnya Ngalim Purwanto mengatakan bahwa: "Belajar adalah setiap perubahan yang terjadi sebagai suatu hasil latihan dan penglaman atau suatu aktivitas mental/psikis yang berlangsung dalam interaksi aktif

${ }^{5}$ E. Mulyasa. Kurikulum Tingkat Satuan Pendidikan, (Bandung: Remaja Rosdakarya, 2006), h. 255

6 Sumardi Suryabrata. Psikologi Pendidikan, (Jakarta: Raja Grafindo Persada, 1997), h. 249 dengan lingkungan yang menghasilkan perubahan-perubahan dalam pengetahuan, pemahaman, keterampilan dan nilai-nilai sikap.Perubahan itu bersifat relatif konstan berbekas."7

Berdasarkan kutipan diatas maka dapat dipahami bahwa belajar menyangkut tentang mental yang mendukung perkembangan anak seperti keterampilan dan pemahaman yang selalu berkembang. Pemahaman dan perkembangan yang mengakibatkan perubahan tersebut juga tidak dapat dipastikan dengan kadar kemampuan dan keberhasilan yang sama bagi setiap orang. Oleh karena itu dalam belajar seorang guru harus mampu memberikan motivasi kepada para siswa agara mau dan mampu belajar dengan tekun dan giat sehingga siswa benar-benar mampu meraih hasil dalam belajar.Dengan demikian, maka nyatalah bahwa seorang guru adalah motivator dalam membangkitkan minat belajar sekaligus meraih hsil belajar siswa.

\section{Pengertian Hasil Belajar}

Seluruh aktivitas siswa adalah untuk mendapatkan hasil belajar yang baik.Oleh karenanya siswa berlomba-

${ }^{7}$ M. Ngalim Purwanto. Psikologi Pendidikan, (Jakarta: Remaja Karya, 1997), h. 85 
Vol. 11, No. 1 (Juni 2019)

lomba untuk mencapainya dengan usaha dilakukan seoptimal mungkin.Dalam hal demikian maka hasil belajar siswa dipastikan sebagai kebutuhan yang memunculkan motivasi dalam diri siswwa untk belajar.Bila suatu waktu siswa memperoleh hasil belajar yang baik, dimana keberhasilan itu jauh dari yang diharapkan, maka siswa belum merasa puas. Kebutuhan siswa untuk memperoleh hasil belajar yang baik belum tercapai pada saat itu, misalnya: tentulaah siswa tersebut berusaha untuk mencapainya di masa akan datang. Oleh karena itu kebutuhan seorang siswa untuk menuntut suatu kepuasan selalu mendorongnya untuk belajar.

Hasi belajar terdiri dari dua kata, yakni: hasil dan belajar. Pengertian hasil belajar adalah: "hasil yang telah dicapai (dilakukan, dikerjakan)." Sementara itu pengertian belajar adalah: "suatu proses usaha yang dilakukan untuk memperoleh perubahan tingkah laku yang baru secara keseluruhan, sebagai hasil

\footnotetext{
${ }^{8}$ M. Sastrapradja. Kamus Istilah Pendidikan dan Umum, (Surabaya: Usaha Nasional, 1997), h. 90
}

pengalamannya sendiri dalam interaksi dengan lingkungannya". 9

Berdasarkan pengertian diatas dapat ditegaskan bahwa kegiatan belajar merupakan suatu tindakan atau usaha untuk dapat melakukan perubahan pada diri pribadi anak didik sehingga ia dapat mengembangkan potensi dirinya, karena kegiatan belajar merupakan suatu langkah untuk mengembangkan kecerdasan yang dimiliki anak didik sehingga perkembangan yang terjadi dewasa ini dapat diikuti. Dengan demikian jelaslah bahwa belajar adalah suatu kegiatan anak didik dalam menerima, menanggapi serta menganalisa bahan-bahan pelajaran yang disajikan oleh guru yang berakhir pada kemampuan anak didik untuk menguasai bahan pelajaran yang disajikan itu. Dengan kata lain bahwa belajar adalah rangkaian proses kegiatan response yang terjadi dalam suatu rangkaian belajar mengajar yang berakhir pada terjadinya perubahan tingkah laku baik jasmaniyah maupun rohaniyah akibat pengalaman belajar atau pengetahuan yang diperoleh.

${ }^{9}$ M. Arifin. Hubungan Timbal Balik Pendidikan Agama di Lingkungan Sekolah dan Keluarga, (Jakarta: Bulan Bintang, 1998), h. 172 
Kemampuan anak didik dalam belajar senantiasa diukur dari kemampuan menangkap pesan-pesan yang disampaikan oleh guru dalam kegiatan belajar mengajar. Keberhsilan anak didik dalam interaksi edukatif ini akan dapat dilihat dari nilai raport yang ada maupun dari sikap dan tingkah lakunya sehari-hari. Perubahan diri siswa dalam proses pembelajaran memiliki 3 (tiga) sifat, yaitu:

1) Perubahan yang bersifat intensional, yaitu perubahan yang terjadi karena pengalaman atau praktek yang dilakukan proses belajar dengan sengaja dan disadari, bukan terjadi secara kebetulan.

2) Perubahan positif-aktif. Perubahan yang bersifat positif yaitu perubahan yang bermanfaat sesuai dengan harapan belajar, disamping menghasilkan sesuatu yang baru dan baik disbanding sebelumnya, sedangkan perubahan yang bersifat aktif yaitu perubahan yang terjadi karena usaha yang dilakukan siswa bukan terjadi dengan sendirinya.

3) Perubahan yang bersifat efektiffungsional. Perubahan yang bersifat efektif yaitu perubahan yang memberikan pengaruh dan manfaat bagi siswa, sedangkan perubahan yang bersifat fungsional yaitu perubahan yang relatif tetap dapat diproduksi atau dimanfaatkan setiap kali dibutuhkan. ${ }^{10}$

\section{Pengertian Keaktifan Belajar}

Kegiatan belajar pada intinya adalah terjadinya perubahan. Ini berarti bahwa seseorang yang telah mengalami proses belajar akan mengalami perubahan tingkah laku, baik aspek pengetahuan, keterampilan, maupun sikapnya, misalnya dari tidak bisa menjadi bisa, dari tidak mengetahui menjadi mengetahui, dari ragu menjadi yakin. Singkatnya aktivitas belajar adalah aktivitas yang dilakukan untuk merubah tingkah laku anak didik kearah yang konstruktif.

Dalam kegiatan belajar terjadi aktivitas, yakni terjadinya transformasi ilmu pengetahuan dan segala perangkat yang berhubungan dengannya dari tenaga pengajar (guru) kepada yang menerima pelajaran (anak didik),

${ }^{10}$ A. Sabri. Strategi Belajar Mengajar dan MikroTeaching, (Jakarta: Quantum teaching, 2005), h. 34 
Vol. 11, No. 1 (Juni 2019)

sebagaimana dijelaskan dalam kutipan berikut: "belajar yang berhasil atau keaktifan belajar mesti melalui berbagai macam aktivitas, baik aktivitas fisik maupun psikis. Aktivitas fisik adalah peserta didik aktif dengan anggota badan, membuat sesuatu, bermain ataupun bekerja, ia tidak hanya duduk dan mendengarkan, melihat atau hanya pasif. Peserta didik yang memiliki aktivitas psikis (kejiwaan) adalah, jika daya jiwanya bekerja sebanyakbanyaknya atau banyak berfungsi dalam rangka pengajaran". ${ }^{11}$

Seorang anak didik akan mengerahkan segala kemampuannya dalam kegiatan belajar supaya kemampuannya tetap aktif untuk mendapatkan hasil belajar secara optimal sekaligus dapat mengikuti proses pengajaran secara aktif. Keaktifan anggota badan (fisik) sebagai kegiatan yang nampak, yaitu saat siswa melakukan percobaan, membuat konstruksi model dan lain-lain. Sedangkan kegiatan psikis nampak bila ia sedang mengamati dengan teliti, memecahkan persoalan, mengambil

${ }^{11}$ Ahmad Rohani HM, Abu Ahmadi, Pengelolaan Pengajaran, (Jakarta: Rineka cipta, 1996), h. 43 keputusan dan sebagainya. Pada saat siswa aktif jasmaninya secara otomatis aktif juga jiwanya, begitu juga sebaliknya. Karena itu keduanya merupakan satu kesatuan yang tidak dapat dipisahkan ibarat dua keping mata uang yang saling mendukung.

\section{Faktor yang Mempengaruhi Hasil Belajar}

Ada beberapa faktor yang mempengaruhi terjadinya aktivitas belajar, seperti dijelakn oleh Chalidjah Hasan bahwa faktor-faktor yang mempengaruhi terjadinya aktivitas belajar antara lain:

1) Faktor yang terjadi pada organism itu sendiri yang disebut dengan faktor individual. Yang termasuk faktor individual adalah faktor kematangan/pertumbuhan,

kecerdasan, latihan, motivasi, dan faktor pribadi.

2) Faktor yang ada diluar individu yang kita sebut dengan faktor. Yang termasuk ke dalam faktor sosial adalah faktor keluarga/keadaan rumah tangga, guru dan cara mengajarnya, alatalat yang dipergunakan dalam belajar mengajar, lingkungan dan 
kesempatan yang tersedia dan motivasi sosial. ${ }^{12}$

Faktor-faktor tersebut sangat besar pengaruhnya terhadap upaya pencapaian hasil belajar siswa. Faktor-faktor tersebut sangat mendukung terselenggaranya kegiatan belajar mengajar, sehingga apa yang menjadi cita-cita dan harapan dapat terwujud dengan baik. Secara umum klasifikasi faktor-faktor yang mempengaruhi aktivitas belajar siswa antara lain:

1) Faktor-faktor yang berasal dari luar diri pelajar, dan ini masih lagi dapat gigolongkan menjadi dua golongan, yaitu:

a) Faktor sosial

Faktor sosial terdiri dari: lingkungan keluarga, lingkungan sekolah, lingkungan masyarakat, lingkungan kelompok.

b) Faktor non sosial

Faktor non sosial ini terdiri dari:

- Faktor budaya seperti adat istiadat, ilmu pengetahuan, teknologi, kesenian

12 Chalidjah Hasan. Dimensi-Dimensi Psikologi Pendidikan, (Surabaya : Al-Ikhlas, 1999), h. 97
- Faktor lingkungan fisik seperti fasilitas rumah, fasilitas belajar, iklim.

- Faktor lingkungan spiritual dan keagamaan. ${ }^{13}$

2) Faktor yang berasal dari dalam si pelajar dan faktor inipun masih dapat digolongkan menjadi dua golongan, yaitu:

a) Faktor fisiologis

Faktor fisiologis (jasmaniah) adalah faktor yang bersifat bawaan maupun yang diperoleh.Yang termasuk faktor ini misalnya penglihatan, pendengaran, struktur tubuh dan lainnya.

b) Faktor psikologis

Semua faktor-faktor ini menentukan keaktifan belaar yang dilakukan siswa baik di sekolah maupun dirumah serta kemampuan siswa meraih hasil belajar secara maksimal. Karena itu perlu adanya pemahaman yang luas dari orang tua dan guru tentang kondisi psikologis anak didik, yang dimaksudkan untuk penyesuaian antara materi pelajaran yang disampaikan dengan daya

\footnotetext{
${ }^{13} \mathrm{Abu}$ Ahmadi, Widodo Supriyono. Psikologi Belajar, (Jakarta : Rineka Cipta, 1991), h. 131
} 
serap siswa terhadap pelajaran yang dimaksud sehingga keberhasilan belajar siswa dapat tercapai yakni siswa akan memperoleh hasil belajar yang baik. Di samping itu dibutuhkan dukungan orang tua terhadap aktivitas belajar yang dilakukan oleh siswa yang akan memotivasi siswa untuk belajar lebih giat lagi di sekolah maupun di rumah.

Keaktifan belajar siswa dapat dilihat dari kegiatan siswa dalam mengikuti proses belajar mengajar yang ditandai dengan:

1) Menyiapkan buku pelajaran yang akan dibahas, dan membuka halaman, pasal, bab yang akan diperbincangkan.

2) Membaca keseluruhan pelajaran yang diperintahkan guru.

3) Mempersiapkan peralatan belajar seperti buku tulis, pulpen, dan sebagainya.

4) Mendengarkan dan mengikuti penjelasan guru dan yang dibaca guru atau siswa terhadap pelajaran.

5) Menjawab pertanyaan guru.

Berdasarkan kutipan di atas, dapat dipahami bahwa keaktifan belajar siswa dapat diukur dengan berbagai kriteria yang ada mulai dari menyiapkan bukubuku materi yang sedang dipelajari sampai membuat catatan tersendiri terhadap kesimpulan yang dipelajari.

Untuk menciptakan keaktifan belajar siswa, seorang guru harus benarbenar mampu menguasai segala sesuatu yang berkaitan dengan tugasnya dan yang lebih penting adalah seorang guru harus benar-benar terlebih dahulu mengamalkan apa yang diajarkan.

Belajar sebagai proses terpadu dipahami sebagai proses yang memungkinkan semua aspek yang meliputi aspek fisik, sosial, emosional, intelektual dan moral. Oleh karena ittu akibat dari kegiatan belajar tidak hanya terdapat salah satu aspek saja melainkan lebih dari itu. Dalam dunia pendidikan dijelaskan bahwa "mengajar bukan sekedar proses penyampaian ilmu pengetahuan, melainkan mengandung makna yang lebih luas, yakni terjadinya interaksi manusiawi dengan berbagai aspek yang cukup kompleks". ${ }^{14}$

Untuk mencapai keberhasilan dalam kegiatan pengajaran bidang studi Agama khususnya di sekolah, guru

\footnotetext{
${ }^{14}$ Moh.Uzer.Usman.Menjadi Guru
} Profesional, (Bandung : Remaja Rosdakarya, 1995), h. 3 
agama perlu melakukan berbagai langkah konkrit yang patut menjadi tolak ukur bagi keberhasilan kegiatan pengajarannya dalam upaya mengantarkan keberhasilan belaar siswa dalam bidang studi Agama Islam.

Agama Islam merupakan suatu bidang studi pengajaran dalam pendidikan merupakan suatu bentuk pemahaman keilmuan kepada seseorang. Pendidikan merupakan salah satu cara yang tidak terlepas dari kehidupan manusia. Manusia dilahirkan tidaklah langsung menjadi dewasa jasmani dan rohani, melainkan harus dididik dan dibimbing untuk mencapai kedewasaan, melalui pendidikan manusia akan mendapatkan bekal hidup dalam kehisupan sebagai makhluk individu maupun makhluk sosial.

Dalam hal pembinaan melalui pendidikan agama anak sesuai dengan tuntutan agama maka tujuan pendidikan Islam menurut Abdul Aziz Rambe merumuskan sebagai berikut :

1) Memperkenalkan kepada anak tentang aqidah Islam dan dasardasarnya, asal-usul ibadah dan cara mengerjakannya.

2) Menumbuhkan kesadaran yang benar pada diri anak terhadap agama, termasuk prinsip dasar akhlak mulia.

3) Menanamkan minat anak untuk menambah pengetahuan dalam keagamaan dan mengikuti hukum agama dengan kecintaan dan kerelaan.

4) Menanamkan rasa cinta dan penghargaan kepada Al-Qur'an.

5) Menumbuhkan rasa bangga terhadap sejarah dan kebudayaan Islam serta pahlawan-pahlawannya dan mau mengikuti mereka.

6) Menumbuhkan rasa rela, optimis, percaya diri, tanggung jawab, menghargai kewajiban dan tolong menolong.

7) Mendidik naluri, motivasi dan keinginan generasi muda dan membentenginya dengan aqidah dan nilai-nlai serta membiasakan mereka menahan, mengatur dan mengimbangi emosi dengan baik.

8) Menanamkan iman yang kuat, menguatkan perasaan keagamaan dan dorongan agama, akhlak dan menyuburkan kecintaan dzikir, taqwa dan takut kepada Allah.

9) Membersihkan hati dari dengki, iri hati, benci kekerasan, kekejaman, 
egois, penipuan, hikmat, munafiq, ragu perpecahan dan perselisihan. ${ }^{15}$

Dengan demikian dari rumusan tersebut diharapkan pendidikan agama Islam dapat membentuk anak-anak yang bermoral, beramal saleh dan berkepribadian yang tinggi sebagai generasi penerus agama Islam dan penerus pembangunan bangsa dan Negara.

Menurut Mansyur tujuan pendidikan dalam Islam adalah:

1) Untuk membantu pembentukan akhlak mulia

2) Persiapan untuk kehidupan dunia dan akhirat

3) Menumbuhkan roh ilmiyah

4) Persiapan untuk mencari rezeki

5) Menyiapkan tenaga profesional. ${ }^{16}$

Berdasarkan penjelasan di atas dapat dipahami bahwa pendidikan agama Islam merupakan pembelajaran dan upaya penanaman tentang pengetahuan agama islam dengan harapan setelah memperoleh pendidikan dan pembelajaran diharapkan menjadi

\footnotetext{
${ }^{15}$ Abdul Aziz Rambe. Sumbangan Pendidikan Islam Dalam Pembangunan Nasional, (Medan : Toha Putra, 1998), h. 2

${ }^{16}$ Mansyur. Strategi Belajar Mengajar, (Jakarta : Bumi Putra, 1991), h. 54
}

manusia yang berilmu pengetahuan, berwawasan, berkualitas, kreatif, bermoral dan berakhlakul karimah.

\section{Metodologi}

Populasi dalam penelitian ini adalah seluruh siswa kelas X SMA AlHidayah Medan yang berjumlah 120 orang.

Dalam penelitian ini penulis menetapkan sampel sebanyak 60 orang dari jumlah populasi dengan ketentuan penarikan sampel yaitu claster random sampling artinya pengambilan sampel berdasarkan class yang ada.

Untuk memperoleh data yang diperlukan maka penulis mengambil data berdasarkan :

1) Observasi yaitu pengamatan langsung ke lapangan untuk melihat secara jelas kondisi objektif yang diteliti.

2) Angket. Dalam hal ini penulis menyebarkan pertanyaan tertulis yang berkaitan dengan keaktifan dan ketidakaktifan belajar siswa.

3) Tes. Penulis memberikan tes sebanyak 10 soal yang berkaitan dengan pelajaran Pendidikan Agama Islam di Kelas X. 
Vol. 11, No. 1 (Juni 2019)

\section{Hasil Penelitian}

Berdasarkan hasil penelitian ditemukan bahwa hasil belajar siswa yang aktif mengikuti kegiatan belajar agama termasuk kategori tinggi dengan nilai rata-rata 7,45 dan standar deviasi 2,37 dibandingkan dengan hasil belajar siswa yang tidak mengikuti kegiatan belajar agama termasuk kategori cukup dengan nilai rata-rata 6,05 dan standar deviasi 10,83 . Karena nilai rata-rata yang aktif mengikuti kegiatan belajar agama lebih tinggi daripada nilai rata-rata yang tidak aktif mengikuti kegiatan belajar agama $(7,45>6,05)$ berarti hasil belajar siswa yang aktif mengikuti kegiatan belajar agama lebih baik daripada prestasi belajar siswa yang tidak aktif mengikuti kegiatan belajar agama.

Siswa yang aktif mengikuti belajar agama menyadari bahwa keaktifan mengikuti belajar merupakan proses belajar mengajar untuk berupaya mengembangkan dan membangkitkan motivasi, rangsangan dan semangat belajar melalui serangkaian mata pelajaran yang diujikan baik dalam ujian semester maupun dalam ujian UAN.

Dari hasil pengujian hipotesis dapat diketahui perbedaan signifikan hasil belajar siswa yang aktif mengikuti kegiatan belajar agama di SMA AlHidayah Medan dengan taraf signifikan $5 \%(0,05)=1,66$ ternyata $\mathrm{t}$-hitung $>\mathrm{t}-$ tabel atau 1,92 > 1,66. Hal ini berarti (Ha) diterima, dan dapat disimpulkan bahwa hasil belajar siswa yang aktif mengikuti kegiatan belajar agama lebih baik daripada hasil belajar siswa yang tidak aktif mengikuti kegiatan belajar agama.

Tingginya hasil belajar siswa yang aktif mengikuti kegiatan belajar pada mata pelajaran Pendidikan Agama Islam di SMA Al-Hidayah Medan menunjukkan bahwa keaktifan belajar sangat besar pengaruhnya terhadap prestasi dan hasil belajar siswa. Oleh karena itu guru agama sangat berperan dalam meningkatkan keaktifan belajar agama siswa. Seorang guru yang bertugas dan bertanggungjawab terhadap pendidikan di sekolah dituntut untuk mampu mengelola pembelajaran agar berjalan dengan baik dan efektif adalah ditandai dengan adanya kesadaran dan keterlibatan aktif di antara dua subjek pengajaran yakni guru sebagai penginisiatif awal, pengarah dan pembimbing sedangkan siswa sebagai peserta yang terlibat aktif. 
INTIQAD: JURNAL AGAMA DAN PENDIDIKAN ISLAM

ISSN 1979-9950 (print) || ISSN 2598-0033 (online), http://jurnal.umsu.ac.id/index.php/intiqad DOI: https://doi.org/10.30596/intiqad.v11i1.2019

Vol. 11, No. 1 (Juni 2019)

Sebaliknya guru yang tidak mampu memotivasi siswa untuk belajar dengan lebih aktif, juga ssangat mempengaruhi terhadap rendahnya prestasi dan hasil belajar siswa. Oleh karena itu, guru harus mampu mengklasifikasikan siswa yang aktif dengan yang tidak aktif. Dengan demikian guru dapat mempertahankan keaktifan belajar siswa yang sudah aktif sekaligus mencari solusi dan jalan keluar bagi permasalahan yang dihadapi siswa atas ketidakaktifannya dalam belajar.

Menciptakan pembelajaran yang afektif adalah preses pembelajaran yang berhasil atau yang mencapai tujuan sebagaimana ditetapkan dengan mendayagunakan sumber belajar yang ada. Guru menggunakan kemampuan profesionalnya untuk menggerakkan sumber daya yang ada sehingga tercapai tujuan pengajaran yang telah ditetapkan.

\section{E. Kesimpulan}

Berdasarkan hasil penelitian yang telah dilakukan maka dapat disimpulkan sebagai berikut:

1. Hasil belajar siswa yang aktir mengikuti kegiatan belajar agama tergolong tinggi, berdasarkan nilai rata-rata belajar siswa yaitu 7,45 , sedangkan hasil belajar siswa yang tidak aktif mengikuti kegiatan belajar agama tergolong cukup berdasarkan nilai rata-rata 6,05.

2. Ada perbedaan hasil belajar siswa yang aktif mengikuti kegiatankegiatan belajar dengan yang tidak aktif mengikuti kegiatan belajar agama. Hal ini terbukti hasil pehitungan hipotesis yaitu $t_{\text {hitung }}>t_{\text {tabel }}$ atau 1,92>1,66 pada taraf signifikan 5\% $(0,05)$.

3. Adanya perbedaan hasil belajar agama siswwa yang aktif dengan yang tidak aktif mengikuti belajar agama siswwa kelas X SMA AlHidayah Medan menunjukkan bahwa peranan guru sangat penting untuk mencari solusi terhadap peningkatan hasil belajar siswa khususnya bagi mereka yang tidak aktif mengikuti pelajaran agama.

\section{Daftar Pustaka}

Ahmadi, Abu. (1997). Psikologi Belajar, Jakarta: Rineka Cipta.

Arifin M. (1998). Hubungan Timbal Balik Pendidikan Agama di Lingkungan Sekolah dan Keluarga, Jakarta: Bulan Bintang. 
INTIQAD: JURNAL AGAMA DAN PENDIDIKAN ISLAM

ISSN 1979-9950 (print) || ISSN 2598-0033 (online), http://jurnal.umsu.ac.id/index.php/intiqad DOI: https://doi.org/10.30596/intiqad.v11i1.2019

Vol. 11, No. 1 (Juni 2019)

Aziz Rambe Abdul. (1998). Sumbangan

Pendidikan Islam Dalam

Pembangunan Nasional, Medan:

Toha Putra.

Hafsah. (2006). Ilmu Fiqh, Medan: PT.

Madju. Medan.

Hasan Chalidjah. (1999). Dimensi-

Dimensi Psikologi Pendidikan,

Surabaya: Al-Ikhlas.

Irwan Nst, Syafaruddin. (2005).

Manajemen Pembelajaran, Jakarta:

Quantum Teaching Press.

Mansyur. (1991). Strategi Belajar

Mengajar, Jakarta: Bumi Putra.

Mulyasa, E. (2006). Kurikulum Tingkat

Satuan Pendidikan, Bandung:

Remaja Rosdakarya.

Purwanto, M. Ngalim. (1997). Psikologi

Pendidikan, Jakarta: Remaja Karya.

Rohani HM Ahmad, Abu Ahmadi.

(1996). Pengelolaan Pengajaran,

Jakarta: Rineka Cipta.

Sabri, A. (2005). Strategi Belajar

Mengajar dan Mikri Teaching,

Jakarta: Quantum Teaching.
Sastrapradja, M. (1997). Kamus Istilah Pendidikan dan Umum, Surabaya: Usaha Nasional.

Suryabrata, Sumardi. (1997). Psikologi Pendidikan, Jakarta: Raja Grafindo Persada.

Tilaar, AR. (1996). Pendidikan Non Formal Sebagai Ide Eksplosif dalam Pendidikan, Jakarta: Konvensi Nasional.

Uzer, Usman Moh. (1995). Menjadi Guru Profesional, Bandung: Remaja Rosdakarya.

Widodo Supriyono, Abu Ahmadi. (1991). Psikologi Belajar, Jakarta: Rineka Cipta. 